\title{
Ferrous oxalate, maghemite and hematite nanorods as efficient adsorbents for decontamination of Congo red dye from aqueous system
}

\author{
J. P. Dhal • B. G. Mishra $\cdot$ G. Hota
}

Received: 25 January 2013/Revised: 10 November 2013/Accepted: 17 February 2014/Published online: 15 March 2014

(C) Islamic Azad University (IAU) 2014

\begin{abstract}
In this present study, we have synthesized ferrous oxalate nanorods by a modified co-precipitation methods. The obtained nanomaterial (ferrous oxalate nanorod) was calcined at higher temperatures to form both maghemite and hematite nanorods. The morphology, size, crystalline phases, formation and surface area of the nanorods were characterized by scanning electron microscope, transmission electron microscope, X-ray diffraction, Fourier transform infrared spectroscope, ultraviolet-visible diffuse reflectance spectroscope and Brunauer-Emmett-Teller surface area analytical techniques. The results showed that high-yield aligned nanorods with a typical diameter of 100-200 nm and length up to micrometers were formed. The obtained rod-shaped nanomaterials (i.e., ferrous oxalate, maghemite and hematite) were used as adsorbents and were applied to remove Congo red (CR) dye molecules, which was used as a model of organic pollutants in aqueous solution. The adsorption isotherms and kinetics of removal of CR were studied. It was found that the adsorption capacity of maghemite nanorod is highest among the three adsorbents and can be regarded as an effective adsorbent for removal of CR from aqueous solution.
\end{abstract}

Keywords Co-precipitation method - Nanomaterials . Nanorod $\cdot$ Congo red $(\mathrm{CR}) \cdot$ Adsorption

\section{Introduction}

Water pollution is a major global problem which is the leading worldwide cause of deaths and diseases. Many synthetic chemicals are extremely resistant to

J. P. Dhal · B. G. Mishra · G. Hota ( $₫)$

Department of Chemistry, N.I.T. Rourkela, Rourkela, Odisha, India

e-mail: garud31@yahoo.com biodegradation by native microorganisms and are major water pollutants, such as pesticides, organochlorines, polychlorinated biphenyls, polycyclic aromatic hydrocarbons, wood preservatives, synthetic polymers and synthetic dyes. Synthetic dyes are extensively used in different industries, including paper, plastic, leather, pharmaceutical, food, cosmetic, dyestuff and textile industries (Ge et al. 2012; Haider et al. 2011). Dyeing is a fundamental operation during the textile fiber processing. This operation causes the production of more or less colored waste waters, depending on the degree of fixation of the dyes on the substrates, which varies with the nature of the substances, the desired intensity of coloration and the application method (Wawrzkiewicz 2012). According to a recent study, approximately 700,000 tons of different dyes are produced annually in the world, and more than $60 \%$ of the world dye production is consumed by textile industries $(\mathrm{Hu}$ et al. 2010a, b). Due to the presence of hazardous wastes and toxic pollutants in the effluents from the textile industry, they are highly problematic to environment. Among them, organic dyes are one of the major groups of pollutants in waste waters. These toxic dyes have significant impact on the human health and the aquatic life. The used dyes may cause an eco-toxic hazard and induce the potential danger of bioaccumulation (Toor and Jin 2012; Wang et al. 2012a, b; Kumar and Bansal 2012).

The toxic nature of dye is that on decomposition it gives hazardous products such as carbon dioxide, carbon monoxide, nitrogen oxide and hydrogen chloride. These products are toxic and causes severe health problem to living beings (Irama et al. 2010). Congo red [1-naphthalene sulfonic acid, 3, 30-(4, 40-biphenylenebis(azo))bis(4-amino-) disodium salt] an anionic dye has been known to cause an allergic reaction and to be metabolised to benzidine, a human carcinogen. Congo red (CR) mainly occurs in the 
effluents discharged from textile, paper, printing, leather industries, etc. Its molecular formula is $\mathrm{C}_{32} \mathrm{H}_{22} \mathrm{~N}_{6} \mathrm{Na}_{2} \mathrm{O}_{6} \mathrm{~S}_{2}$ (Yosef and Avnir 2011; Chatterjee et al. 2010).

There are several methods for removal of organic dyes from aqueous solution such as coagulation (Marechal et al. 1997), nanofiltration (Chakraborty et al. 2003), ozonation (Khadhraoui et al. 2009), ultrasound irradiation (Song et al. 2009), ion exchange (Wawrzkiewicz and Hubicki 2010), activated carbon filter (Chan et al. 2009), oxidation (Lucas and Peres 2006), membrane processes (Sachdeva and Kumar 2009), micellar-enhanced ultrafiltration (Purkait et al. 2004) and adsorption (Wang et al. 2012a, b). Among all the processes, adsorption is a very effective separation technique and now it is considered as superior to other techniques for water treatment in terms of effectiveness, initial cost, simplicity of design, and ease of operation and insensitive to toxic substances and its environmentally friendly reasons. Similarly, this technique can handle fairly large flow rates, producing a high-quality effluent that does not result in the formation of harmful substances, such as ozone and free radicals. In this process, the dye species are transferred from the water effluent to a solid phase that leads to decrease the effluent volume (Dawood and Sen 2012; Toor and Jin 2012; Wang et al. 2012a, b; Zhu et al. 2012a, b).

Many researchers used various adsorbent for removal of CR from aqueous solution such as fly ash (Dizge et al. 2008), bentonite (Lian et al. 2009), montmorillonite (Wang and Wang 2008), chitosan (Chatterjee et al. 2009), organoattapulgite (Chen and Zhao 2009), activated carbon (Lorenc-Grabowska and Gryglewicz 2007; Namasivayam and Kavitha 2002; Purkait et al. 2007), bottom ash and deoiled soya (Mittal et al. 2009), Azadirachta indica leaf powder (Bhattacharyya and Sharma 2004), Trametes versicolor (Binupriya et al. 2008), jute stick powder (Panda et al. 2009), Aspergillus niger (Fu and Viraraghavan 2002), cattail root (Hu et al. 2010a, b), anilinepropylsilica xerogel (Pavan et al. 2008), perlite (Vijayakumar et al. 2009), sawdust (Jain and Sikarwar 2008), rice husk ash (Chowdhury et al. 2009), mesoporous hematite $\left(\alpha-\mathrm{Fe}_{2} \mathrm{O}_{3}\right)(\mathrm{Yu}$ et al. 2008) and CNTs/ $\beta-F e O O H$ (Song et al. 2012). However, some of these adsorbents do not have good adsorption capacities for anionic dyes. Nowadays, research focused on the use of nanotechnology for environmental clean-up/ remediation. Arising out of their ultrafine size, large surface area and interface-dominated properties, nano-sized materials can be used to decontaminate the toxic organic and inorganic chemical from the environments. Recently, Afkhami and Moosavi (2010) used maghemite nanoparticle, prepared by co-precipitation method, for removal of CR from aqueous solution.

In the present investigation, by using a modified wet chemical method, we have prepared different 1-dimensional nano-adsorbents such as ferrous oxalate
$\left(\mathrm{FeC}_{2} \mathrm{O}_{4} \cdot 2 \mathrm{H}_{2} \mathrm{O}\right)$ nanorod, hematite $\left(\alpha-\mathrm{Fe}_{2} \mathrm{O}_{3}\right)$ nanorod and maghemite $\left(\gamma-\mathrm{Fe}_{2} \mathrm{O}_{3}\right)$ nanorod. The prepared adsorbents were employed for removal of $\mathrm{CR}$, and a comparative study was carried out by evaluating equilibrium isotherms and kinetic data for selection of the most effective adsorbent among them. The advantages of using iron oxide nanomaterials as adsorbents are as follows: They are most stable material under ambient conditions and have a great scientific and technological importance because of their n-type semiconducting properties with their narrow band gap around $2 \mathrm{eV}$, chemical stability and nontoxicity.

This research work was carried out in Rourkela, India, during the period of March 2012 to November 2012.

\section{Materials and methods}

\section{Materials}

Congo red (CR, molecular formula $\mathrm{C}_{32} \mathrm{H}_{22} \mathrm{~N}_{6} \mathrm{Na}_{2} \mathrm{O}_{6} \mathrm{~S}_{2}$, molecular weight $696.66 \mathrm{~g} \mathrm{~mol}^{-1}, \lambda_{\max }=498 \mathrm{~nm}$ ), an anionic azo dye, obtained from Merck (India) was selected as dye.

Synthesis of adsorbent

All chemicals used in the investigation such as Ferrous sulfate heptahydrate, oxalic acid dihydrate, CTAB and ethanol were of analytical grade and were used without further purification. The chemicals were obtained from Merck (India).

Ferrous sulfate heptahydrate $\left(\mathrm{FeSO}_{4} \cdot 7 \mathrm{H}_{2} \mathrm{O}\right)$ was dissolved in $10 \mathrm{~mL}$ of double-distilled water with intensive stirring to form solution-A. Oxalic acid dihydrate $\left(\mathrm{H}_{2} \mathrm{C}_{2} \mathrm{O}_{4} \cdot 2 \mathrm{H}_{2} \mathrm{O}\right)$ and CTAB (Cetyl trimethylammonium bromide) were dissolved in $25 \mathrm{~mL}$ of ethanol with intensive stirring to form solution-B. Then, solution-A was added to solution-B with intensive stirring to form a yellow colored homogeneous solution. After addition, the stirring was carried out for another $5 \mathrm{~h}$. Then, the yellow colored precipitate obtained was centrifuged, washed thoroughly by ethanol and double-distilled water and dried at $80{ }^{\circ} \mathrm{C}$ for $2 \mathrm{~h}$ to form $\mathrm{FeC}_{2} \mathrm{O}_{4} \cdot 2 \mathrm{H}_{2} \mathrm{O}$ nanorod. A part of this nanopowder was heated at $300{ }^{\circ} \mathrm{C}$ in moist condition to obtained $\gamma-\mathrm{Fe}_{2} \mathrm{O}_{3}$ nanorod and heated at $550{ }^{\circ} \mathrm{C}$ to obtained $\alpha-\mathrm{Fe}_{2} \mathrm{O}_{3}$ nanorod.

\section{Characterization of adsorbent}

Various characterization techniques were used to characterize the 1-D nanoadsorbents. The crystalline phases were identified by mean of X-ray diffraction (XRD) by a PANalytical $\mathrm{X}$-ray diffractometer with $\mathrm{Cu} \mathrm{K} \alpha$ radiation ( $\lambda$ ) $1.54156 \AA$ at a scan rate of $2 \% \mathrm{~min}$. The surface morphology 
of the prepared adsorbent materials was characterized by a JEOL JSM-5300 scanning electron microscope (SEM) operated at an acceleration voltage of 15 and $20.0 \mathrm{kV}$. The size of the particle and selected area electron diffraction (SAED) pattern of the dried $\gamma-\mathrm{Fe}_{2} \mathrm{O}_{3}$ powder were observed using a high-resolution transmission electron microscope (TEM) (JEM-2100 HRTEM, Make-JEOL, Japan) with an acceleration voltage of $200 \mathrm{kV}$. Fourier transform infrared spectroscopy (FTIR) results were recorded using PerkinElmer FTIR (Spectrum RX-I) spectrophotometer. The ultraviolet-visible diffuse reflectance spectra (UV-Vis DRS) of the sample were recorded using Shimadzu spectrometer (model 2450) with $\mathrm{BaSO}_{4}$ coated integration sphere in the range of 200-800 $\mathrm{nm}$. Specific surface area and pore size distribution (PSD) were determined by the Brunauer-Emmett-Teller (BET) and Barrett-Joyner-Halenda (BJH) methods, respectively, by $\mathrm{N}_{2}$ adsorption-desorption technique by automated surface area and porosity analyser (COULTER SA 3100 Series Surface Area and Pore Analyzers). Prior to the analysis, sample was degassed under a vacuum $\left(1 \times 10^{-5}\right.$ Torr $)$ at $150{ }^{\circ} \mathrm{C}$ for $1.5 \mathrm{~h}$.

\section{Adsorption experiment}

For the removal of $\mathrm{CR}$ dye from water, the adsorption experiments were carried out using the three prepared adsorbents: $\mathrm{FeC}_{2} \mathrm{O}_{4} \cdot 2 \mathrm{H}_{2} \mathrm{O}, \alpha-\mathrm{Fe}_{2} \mathrm{O}_{3}$ and $\gamma-\mathrm{Fe}_{2} \mathrm{O}_{3}$ nanorods. A stock solution of $\mathrm{CR}\left(1 \mathrm{~g} \mathrm{~L}^{-1}\right)$ was prepared in doubledistilled water, and desired concentrations of the dye were obtained by diluting the same with double-distilled water. The calibration curve of CR was prepared by measuring the absorbance of different concentrations of the samples at $\lambda_{\max }=498 \mathrm{~nm}$ using UV-vis spectrophotometer, as CR has a maximum absorbance at wavelength $498 \mathrm{~nm}$ on a UV-vis spectrophotometer.

Figure 1 shows the UV-vis spectra of CR solutions of concentration $100 \mathrm{mg} \mathrm{L}^{-1}$ before and after adsorption using $0.05 \mathrm{~g}$ of different adsorbents, such as $\mathrm{FeC}_{2} \mathrm{O}_{4} \cdot 2 \mathrm{H}_{2} \mathrm{O}$ nanorod, $\gamma-\mathrm{Fe}_{2} \mathrm{O}_{3}$ nanorod and $\alpha-\mathrm{Fe}_{2} \mathrm{O}_{3}$ nanorod with reaction time $30 \mathrm{~min}$. At a $\gamma-\mathrm{Fe}_{2} \mathrm{O}_{3}$ dosage of $0.05 \mathrm{~g}^{-1}$, the colloidal suspension is able to adsorb almost $100 \%$ of CR (Fig. 1), and the photograph of before and after adsorption also confirms the removal of the CR at this dosage of $\gamma$ $\mathrm{Fe}_{2} \mathrm{O}_{3}$ (Fig. 1, inset).

The amount of adsorption $q_{\mathrm{e}}$ is calculated by equation (Nethaji et al. 2012):

$q_{\mathrm{e}}=\frac{C_{0}-C_{\mathrm{e}}}{w} V$

where $q_{\mathrm{e}}$ is the amount of adsorption at equilibrium in $\mathrm{mg} \mathrm{g}^{-1}$, $C_{0}$ and $C_{\mathrm{e}}$ are the initial and equilibrium concentration of the dye in $\mathrm{mg} \mathrm{L}^{-1}, V$ is the volume of the dye solution taken in liter and $\mathrm{w}$ is the weight of the nanorod (adsorbent) in gram.

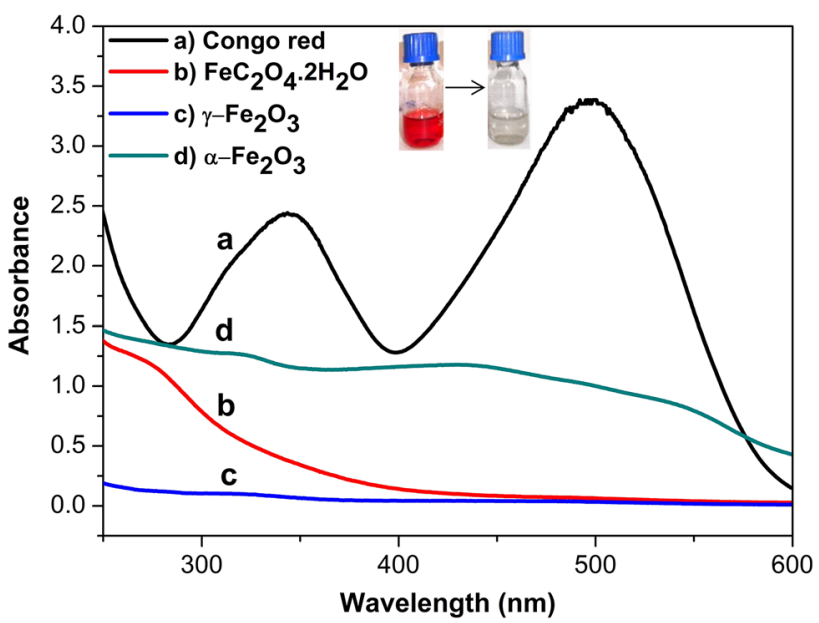

Fig. 1 UV-vis absorption spectra of $(a)$ initial CR with a concentration of $100 \mathrm{mg} \mathrm{L}^{-1}$ and solutions $(20 \mathrm{~mL})$ after treated with $0.05 \mathrm{~g}$ of (b) $\mathrm{FeC}_{2} \mathrm{O}_{4} \cdot \mathbf{2} \mathrm{H}_{2} \mathrm{O}$, (c) $\gamma-\mathrm{Fe}_{2} \mathrm{O}_{3}$ and $(d) \alpha-\mathrm{Fe}_{2} \mathrm{O}_{3}$ for $30 \mathrm{~min}$

\section{Results and discussion}

Surface morphology

Figure 2 shows the SEM micrographs of as synthesized $\mathrm{FeC}_{2} \mathrm{O}_{4} \cdot 2 \mathrm{H}_{2} \mathrm{O}$ nanorod, $\gamma-\mathrm{Fe}_{2} \mathrm{O}_{3}$ nanorod and $\alpha-\mathrm{Fe}_{2} \mathrm{O}_{3}$ nanorod. Figure 2a SEM micrograph suggests that the obtained $\mathrm{FeC}_{2} \mathrm{O}_{4} \cdot 2 \mathrm{H}_{2} \mathrm{O}$ nanostructure exhibits the morphology of the nanorod with the diameter of about 100-200 nm and the length up to micrometers. Moreover, the surface of the $\mathrm{FeC}_{2} \mathrm{O}_{4} \cdot 2 \mathrm{H}_{2} \mathrm{O}$ nanorods seems smooth, and no defects can be observed. When the $\mathrm{FeC}_{2} \mathrm{O}_{4} \cdot 2 \mathrm{H}_{2} \mathrm{O}$ nanorods were annealed in air at $300{ }^{\circ} \mathrm{C}$ in moist condition, $\gamma-\mathrm{Fe}_{2} \mathrm{O}_{3}$ nanorods were fabricated. Figure $2 \mathrm{~b}$ shows the SEM image of the as-synthesized $\gamma-\mathrm{Fe}_{2} \mathrm{O}_{3}$ nanorods. It can be seen that the as-synthesized $\gamma-\mathrm{Fe}_{2} \mathrm{O}_{3}$ nanorods retain the morphology of the $\mathrm{FeC}_{2} \mathrm{O}_{4} \cdot 2 \mathrm{H}_{2} \mathrm{O}$ nanorods. Similarly, when the $\mathrm{FeC}_{2} \mathrm{O}_{4} \cdot 2 \mathrm{H}_{2} \mathrm{O}$ nanorods were annealed in air at $550{ }^{\circ} \mathrm{C}, \alpha-\mathrm{Fe}_{2} \mathrm{O}_{3}$ nanorods were fabricated. Figure $2 \mathrm{c}$ shows the SEM image of the as-synthesized $\alpha-\mathrm{Fe}_{2} \mathrm{O}_{3}$ nanorods. It can also be seen that the as-synthesized $\alpha$ $\mathrm{Fe}_{2} \mathrm{O}_{3}$ nanorods retain the morphology of the $\mathrm{FeC}_{2} \mathrm{O}_{4} \cdot 2 \mathrm{H}_{2} \mathrm{O}$ nanorods. Figure $2 \mathrm{~d}$ shows the EDX analysis of as-synthesized $\gamma-\mathrm{Fe}_{2} \mathrm{O}_{3}$ nanorods, in which presence of $\mathrm{Fe}$ and $\mathrm{O}$ is indicated.

A typical profile of TEM images of $\gamma-\mathrm{Fe}_{2} \mathrm{O}_{3}$ is shown in Figure $3 \mathrm{a}$ and $\mathrm{b}$, which gives further evidence of the formation of high-yield aligned nanorods. A typical TEM image of a single $\gamma-\mathrm{Fe}_{2} \mathrm{O}_{3}$ nanorod is given in Fig. 3c, which gives the average diameter of the rod is around $100 \mathrm{~nm}$. The SAED pattern taken from the same single nanorod (given in Fig. 3d) shows sharp bright rings which indicates it is the polycrystalline spinel structure. 
Fig. 2 SEM micrographs of a $\mathrm{FeC}_{2} \mathrm{O}_{4} \cdot 2 \mathrm{H}_{2} \mathrm{O}$ nanorod, b $\gamma$ $\mathrm{Fe}_{2} \mathrm{O}_{3}$ nanorod, $\mathbf{c} \alpha-\mathrm{Fe}_{2} \mathrm{O}_{3}$ and d EDX of $\gamma-\mathrm{Fe}_{2} \mathrm{O}_{3}$ nanorod

Fig. 3 a-c TEM images and d SAED pattern of $\gamma-\mathrm{Fe}_{2} \mathrm{O}_{3}$ nanorod
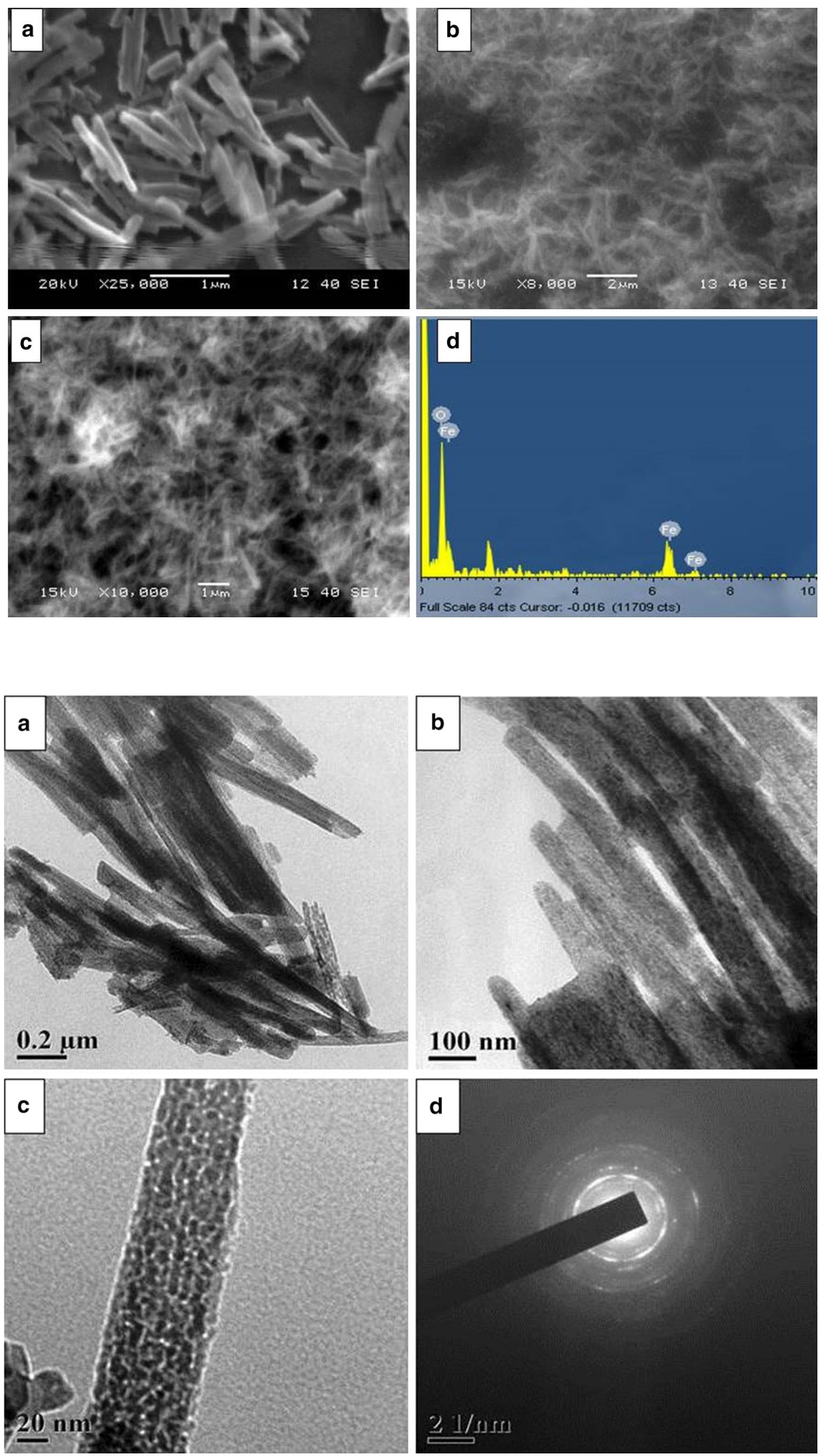
X-ray diffraction analysis

The formation and phase analysis of the prepared nanomaterials was studied by XRD using $\mathrm{Cu} K \alpha$ radiation. Figure 4 shows the XRD patterns of as synthesised $\mathrm{FeC}_{2} \mathrm{O}_{4} \cdot 2 \mathrm{H}_{2} \mathrm{O}$ nanorod, $\gamma-\mathrm{Fe}_{2} \mathrm{O}_{3}$ nanorod and $\alpha-\mathrm{Fe}_{2} \mathrm{O}_{3}$ nanorod. Figure $4 \mathrm{a}$ is the XRD pattern of $\mathrm{FeC}_{2} \mathrm{O}_{4} \cdot 2 \mathrm{H}_{2} \mathrm{O}$ and contains the characteristics peaks and can be index to orthorhombic crystal structure according to JCPDS No: 22-0635. Figure $4 \mathrm{~b}$ contains the characteristics peaks of $\gamma-\mathrm{Fe}_{2} \mathrm{O}_{3}$ and can be index to cubic crystal structure according to JCPDS No: 39-1346. The XRD pattern of Fig. $4 c$ contains the characteristics peaks of $\alpha-\mathrm{Fe}_{2} \mathrm{O}_{3}$ and can be index to rhombohedral according to JCPDS No: 79-0007. In Fig. 4b, it is observed that along with peaks of $\gamma-\mathrm{Fe}_{2} \mathrm{O}_{3}$, some additional peaks are present (star marked). These are due to presence of small amount of $\alpha$ $\mathrm{Fe}_{2} \mathrm{O}_{3}$ in the sample. The X-ray diffractograms reveal the well crystalline nature of the compounds. The broadening of the peaks also indicates the decrease in the diameter and an increase in the surface-to-volume ratio of the compounds. Crystallite size and the lattice strain of the

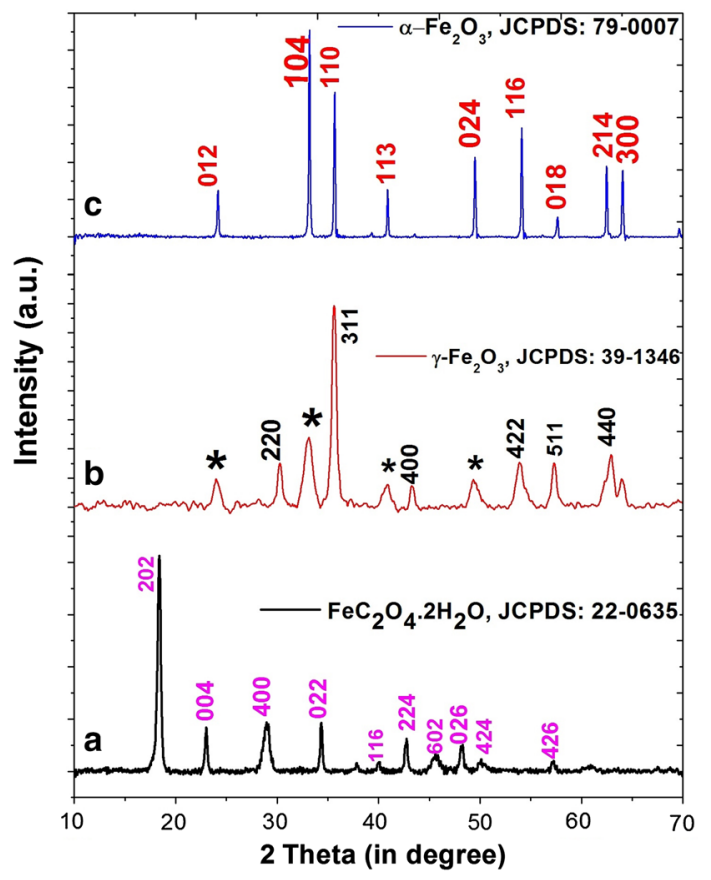

Fig. 4 XRD patterns of (a) $\mathrm{FeC}_{2} \mathrm{O}_{4} \cdot 2 \mathrm{H}_{2} \mathrm{O}$ nanorod, (b) $\gamma-\mathrm{Fe}_{2} \mathrm{O}_{3}$ nanorod and $(c) \alpha-\mathrm{Fe}_{2} \mathrm{O}_{3}$ nanorod prepared samples are calculated from the X-ray diffractograms. From the well-known Scherrer formula, the average crystallite size, $L$, is:

$L=\frac{K \lambda}{\beta \cos \theta}$

where $\lambda$ is the $\mathrm{X}$-ray wavelength, $\theta$ is the diffraction angle, $\beta$ is the line broadening at half the maximum intensity (FWHM) in radians resulting from small crystallite size and $K$ is a constant approximately equal to unity and related to crystallite shape. The crystallite size and lattice strain of ferrous oxalate were found to be $22.6 \mathrm{~nm}$ and $1.196 \%$, respectively. When it is heated to $300{ }^{\circ} \mathrm{C}$ form $\gamma-\mathrm{Fe}_{2} \mathrm{O}_{3}$, its crystallite size increased to $29.4 \mathrm{~nm}$ while lattice strain decreased to 0.5. Similarly, when the sample further heated to higher temperature to form $\alpha-\mathrm{Fe}_{2} \mathrm{O}_{3}$, its crystallite size still increases and lattice strain decreases. This phenomenon is also observed in the XRD patterns that for ferrous oxalate consists broadened peaks and $\gamma-\mathrm{Fe}_{2} \mathrm{O}_{3}$ consists less broadened peaks while $\alpha-\mathrm{Fe}_{2} \mathrm{O}_{3}$ contains comparatively sharp peaks. As the lattice strain of $\alpha-\mathrm{Fe}_{2} \mathrm{O}_{3}$ is least, it is the most stable form among the three samples. The unit-cell dimension of the synthesized samples was measured to determine the crystal structure and given in Table 1 .

FTIR study

To further confirm the formation and transformation from $\mathrm{FeC}_{2} \mathrm{O}_{4} \cdot 2 \mathrm{H}_{2} \mathrm{O}$ to $\gamma-\mathrm{Fe}_{2} \mathrm{O}_{3}$ and $\alpha-\mathrm{Fe}_{2} \mathrm{O}_{3}$, FTIR analysis was performed. In Fig. 5a pattern, the peaks at 3,358, 1,631, 1,315 and $496 \mathrm{~cm}^{-1}$ are attributed to $\mathrm{O}-\mathrm{H}, \mathrm{C}=\mathrm{O}, \mathrm{C}-\mathrm{O}$ and $\mathrm{Fe}-\mathrm{O}$ functional groups, respectively, indicating the formation of $\mathrm{FeC}_{2} \mathrm{O}_{4} \cdot 2 \mathrm{H}_{2} \mathrm{O}$. In Fig. $5 \mathrm{~b}$ pattern, the peak at $632 \mathrm{~cm}^{-1}$ is due to $\mathrm{Fe}-\mathrm{O}$, which is characteristic peak of maghemite and at $1,637 \mathrm{~cm}^{-1}$ is due to presence of water of crystallization in the sample. In Fig. $5 c$ pattern, the peaks at $617 \mathrm{~cm}^{-1}$ is due to longitudinal adsorption $\left(A_{u}\right)$ and at 572 and $490 \mathrm{~cm}^{-1}$ are due to transverse adsorption $\left(E_{u}\right)$ of $\mathrm{Fe}-\mathrm{O}$ vibrational mode of hematite.

UV-vis diffuse reflectance spectra

The optical characterization of the prepared nanomaterials such as electronic transition and band energy gap was done by UV-visible absorbance spectra. The spectral absorption coefficient, $\alpha$, is defined as,

Table 1 Crystallographic information of the prepared nanorods

\begin{tabular}{lllll}
\hline Sample & Crystal structure & Lattice parameters $\left({ }^{\circ} \mathrm{A}\right)$ & Crystallite size $(\mathrm{nm})$ & Lattice strain $(\%)$ \\
\hline $\mathrm{FeC}_{2} \mathrm{O}_{4} \cdot 2 \mathrm{H}_{2} \mathrm{O}$ & Orthorhombic & $a=12.26, b=5.57, c=15.48$ & 22.6 & 1.196 \\
$\gamma-\mathrm{Fe}_{2} \mathrm{O}_{3}$ & Cubic & $a=8.3515$ & 29.4 & 0.5 \\
$\alpha-\mathrm{Fe}_{2} \mathrm{O}_{3}$ & Rhombohedral & $a=b=5.0285, c=13.736$ & 39.1 & 0.433 \\
\hline
\end{tabular}


$\alpha(\lambda)=\frac{4 \pi k(\lambda)}{\lambda}$

where $(\lambda)$ is the spectral extinction coefficient obtained from the absorption curve and $\lambda$ is the wavelength. Figure 6 shows the visible and near-UV diffuse reflectance spectra of the ferrous oxalate and the two iron oxides. From the spectrum of ferrous oxalate, it is observed that there is an intense band around $210 \mathrm{~nm}$ and an asymmetric band at $400 \mathrm{~nm}$. The intense band corresponds to the charge transfer band and the less intense band arises due to ${ }^{5} T_{2 g} \rightarrow{ }^{5} E_{g}$. In case of $\gamma-\mathrm{Fe}_{2} \mathrm{O}_{3}$ spectrum, it is observed that absorption peaks at 302, 357 and

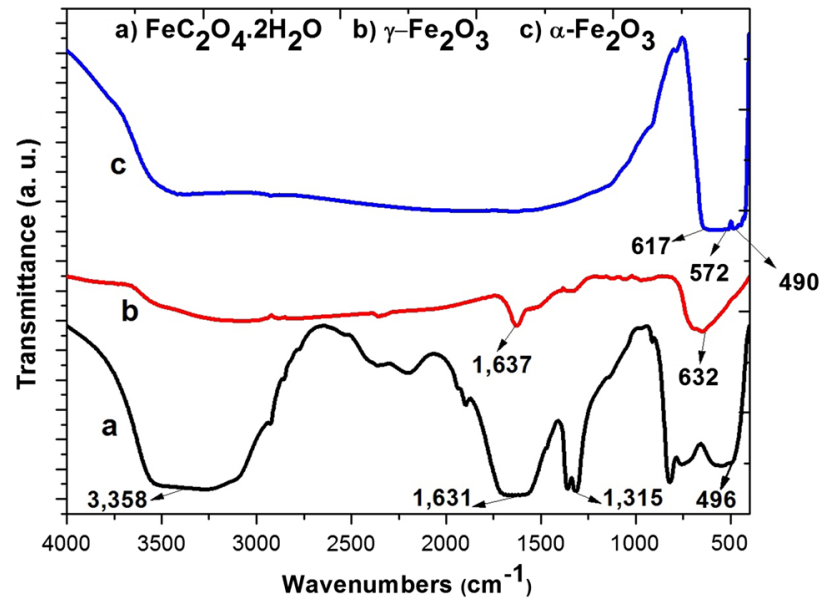

Fig. 5 FTIR spectra of (a) $\mathrm{FeC}_{2} \mathrm{O}_{4} \cdot 2 \mathrm{H}_{2} \mathrm{O}$ nanorod, (b) $\gamma-\mathrm{Fe}_{2} \mathrm{O}_{3}$ nanorod and $(c) \alpha-\mathrm{Fe}_{2} \mathrm{O}_{3}$ nanorod
$421 \mathrm{~nm}$ correspond to ${ }^{6} A_{1} \rightarrow{ }^{4} T_{1}, \quad{ }^{6} A_{1} \rightarrow{ }^{4} E$ and $2\left({ }^{6} A_{1}\right) \rightarrow 2\left({ }^{4} T_{1}\right)$ ligand-free transition of $\mathrm{Fe}^{+3}$, respectively, while the peak at $512 \mathrm{~nm}$ corresponds to finger print region of the band edge of maghemite (Sherman and Waite 1985). From the spectrum of $\alpha-\mathrm{Fe}_{2} \mathrm{O}_{3}$, it is observed that absorption peaks at 339, 355, 484 and $537 \mathrm{~nm}$. The peaks at 355 and $484 \mathrm{~nm}$ correspond to ${ }^{6} A_{1} \rightarrow{ }^{4} E$ and $2\left({ }^{6} A_{1}\right) \rightarrow 2\left({ }^{4} T_{1}\right)$ ligand field transition of $\mathrm{Fe}^{3+}$, respectively. Again, the peak at $537 \mathrm{~nm}$ corresponds to finger print region of the band edge of hematite. This experiment further confirms the formation of pure $\alpha$ $\mathrm{Fe}_{2} \mathrm{O}_{3}$ (Zhu et al. 2012a, b). The optical band gap $E_{g}$ can be experimentally obtained from absorption coefficient measurements using Tauc's formula (Miller et al. 2004):

$(\alpha h v)=A\left(h v-E_{g}\right)^{n}$

where $\alpha$ is the absorption coefficient, $A$ is a constant and $n$ is equal to $1 / 2$ for allowed direct transitions and 2 for allowed indirect transitions. The band gap value, $E_{g}$, of the prepared nanorods was evaluated by extrapolating the linear portion of the curve. It is found that the energy band gaps of $\mathrm{FeC}_{2} \mathrm{O}_{4} \cdot 2 \mathrm{H}_{2} \mathrm{O}, \gamma-\mathrm{Fe}_{2} \mathrm{O}_{3}$ and $\alpha-\mathrm{Fe}_{2} \mathrm{O}_{3}$ are $2.24,1.95$ and $2.04 \mathrm{eV}$, respectively. So, it may be considered that all the prepared nanorods possess semiconducting properties with narrow band gap.

$\mathrm{N}_{2}$ adsorption-desorption isotherm

The surface area and porosity nature of the prepared nanorods was carried out by $\mathrm{N}_{2}$ adsorption-desorption isotherm
Fig. 6 a Visible and nearultraviolet absorption spectra of $\mathrm{FeC}_{2} \mathrm{O}_{4} \cdot 2 \mathrm{H}_{2} \mathrm{O}, \gamma-\mathrm{Fe}_{2} \mathrm{O}_{3}$ and $\alpha$ $\mathrm{Fe}_{2} \mathrm{O}_{3}$ and Tauc plots of b $\mathrm{FeC}_{2} \mathrm{O}_{4} \cdot 2 \mathrm{H}_{2} \mathrm{O}$, c $\gamma-\mathrm{Fe}_{2} \mathrm{O}_{3}$ and d $\alpha-\mathrm{Fe}_{2} \mathrm{O}_{3}$
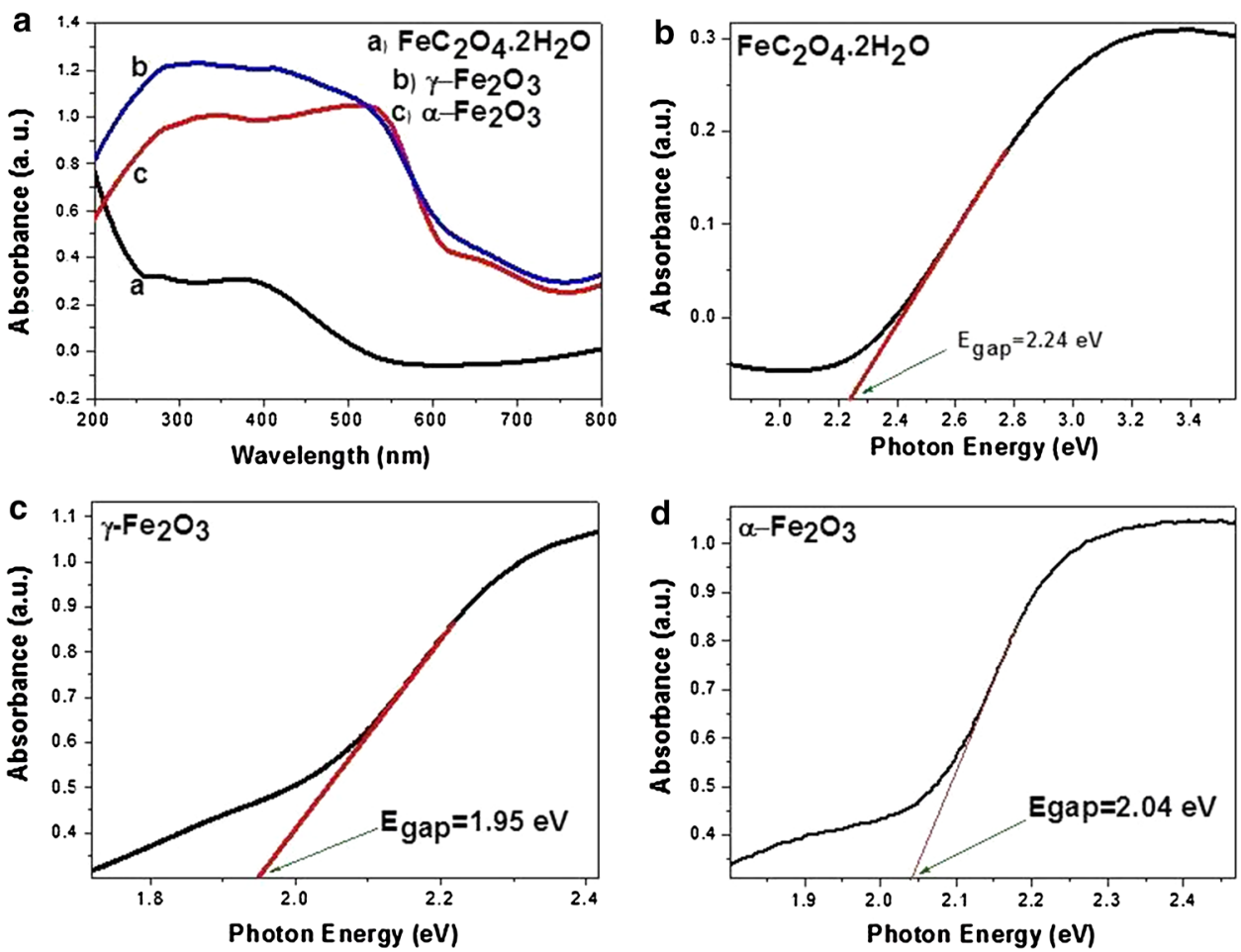
technique. The adsorption-desorption isotherm and pore size distribution are shown in Fig. 7. From Fig. 7a, it is observed that the BET and Langmuir surface areas of the prepared ferrous oxalate were found to be 27.550 and $24.945 \mathrm{~m}^{2} \mathrm{~g}^{-1}$. From the $\mathrm{BJH}$ graph, the pore volume and average pore diameter were found to be $0.0857 \mathrm{~mL} \mathrm{~g}$ and $7 \mathrm{~nm}$, respectively. From Fig. 7b, the BET and Langmuir surface areas of $\gamma-\mathrm{Fe}_{2} \mathrm{O}_{3}$ were found to be 129.74 and $107.35 \mathrm{~m}^{2} \mathrm{~g}^{-1}$, and from the $\mathrm{BJH}$ graph, the pore volume and average pore diameter were found to be $0.1744 \mathrm{~mL} \mathrm{~g}^{-1}$ and $6 \mathrm{~nm}$, respectively. Similarly, from Fig. 7c, the BET and Langmuir surface areas of $\alpha-\mathrm{Fe}_{2} \mathrm{O}_{3}$ were found to be 22.785 and $20.575 \mathrm{~m}^{2} \mathrm{~g}^{-1}$, and from the $\mathrm{BJH}$ graph, the pore volume and average pore diameter were found to be $0.03445 \mathrm{~mL} \mathrm{~g}^{-1}$ and $9 \mathrm{~nm}$, respectively. From the above discussion, it is observed that the surface area of $\gamma-\mathrm{Fe}_{2} \mathrm{O}_{3}$ is highest among the prepared nanorods.

\section{Effect of operational factors on adsorption}

\section{Effect of adsorbent dose}

Adsorbent dosage is one of the most important parameter that has been considered to determine the optimum condition for the performance of adsorption. Essentially, insufficient dosage or overdosing would result in the poor performance in adsorption. Therefore, it is significant to determine the optimum dosage in order to minimize the dosing cost and sludge formation and also to obtain the optimum performance in treatment. The effect of adsorbent doses on the removal of CR using $\mathrm{FeC}_{2} \mathrm{O}_{4} \cdot 2 \mathrm{H}_{2} \mathrm{O}, \alpha-\mathrm{Fe}_{2} \mathrm{O}_{3}$ and $\gamma$ $\mathrm{Fe}_{2} \mathrm{O}_{3}$ nanorods maintaining $\mathrm{pH} 7.6$ ( $\mathrm{pH}$ at normal condition) for $20 \mathrm{~mL}$ of $100 \mathrm{mg} \mathrm{L}^{-1} \mathrm{CR}$ solution and 30 min contact time is represented in Fig. 8a. It is observed there is a continuous removal of $\mathrm{CR}$ with increase in adsorbent dose up to $0.05 \mathrm{~g}$. This may be due to an increase in number of active sites of the adsorbent material with increasing amount of the adsorbent. Further increase in the amount of the adsorbent does not bring any considerable change in the adsorption, i.e., approximately straight line after $0.05 \mathrm{~g}$ thus $0.05 \mathrm{~g}$ was chosen as the optimum amount for all studies of the adsorbents. The highest percentage of removal obtained for $\gamma$ $\mathrm{Fe}_{2} \mathrm{O}_{3}$ nanorod among the three adsorbents.

\section{Effect of contact time}

The time of contact of adsorption is another parameter for adsorption. It is helpful in understanding the amount of dye adsorbed at various time intervals by a fixed amount of the adsorbent. In this section, $0.05 \mathrm{~g}$ of each adsorbents used in $20 \mathrm{~mL} 100 \mathrm{mg} \mathrm{L}^{-1}$ of CR solution maintaining $\mathrm{pH}$ 7.6, with varying time from 0 to $60 \mathrm{~min}$. From Fig. 8b, it is found that there is a consistent increase in percentage of removal up to $30 \mathrm{~min}$ and the adsorption equilibrium is attained after $30 \mathrm{~min}$ of contact time. This is due to the rate of adsorption decreased, and a saturation stage was attained due to the accumulation of the adsorption sites by the dye ions. The highest removal of
Fig. 7 BET isotherm and BJH isotherm (inset) of a ferrous oxalate, $\mathbf{b} \gamma-\mathrm{Fe}_{2} \mathrm{O}_{3}$ and $\mathbf{c} \alpha$ $\mathrm{Fe}_{2} \mathrm{O}_{3}$ nanorods
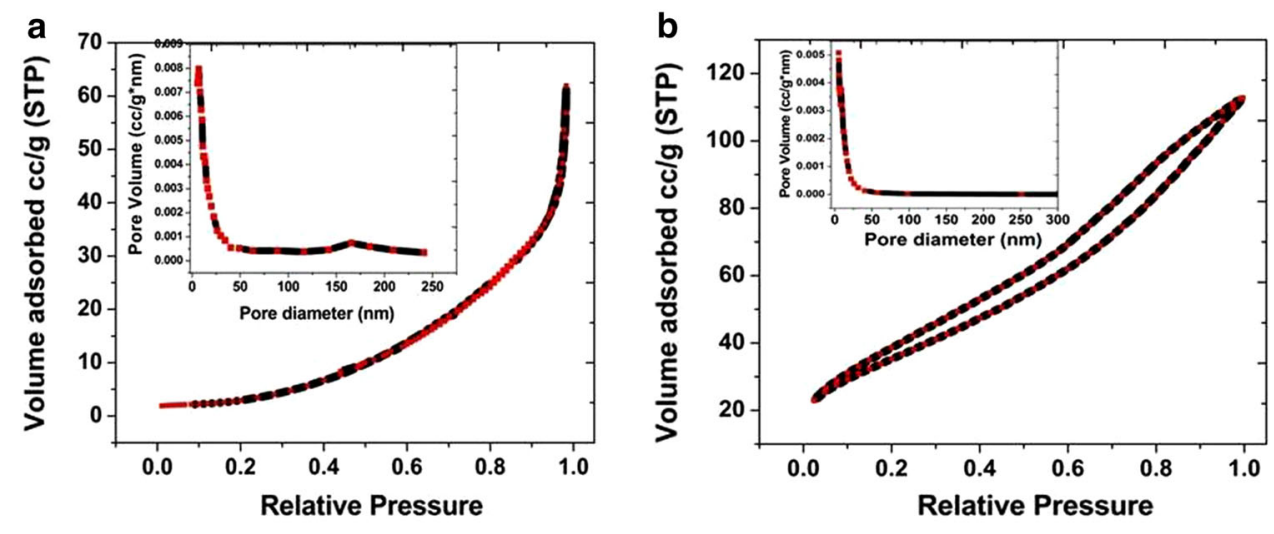

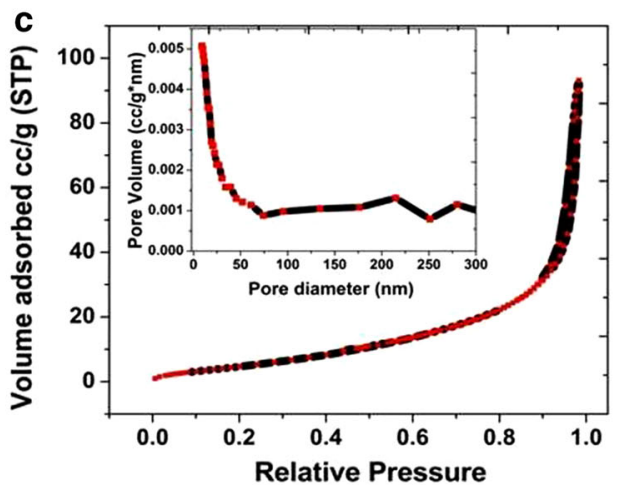



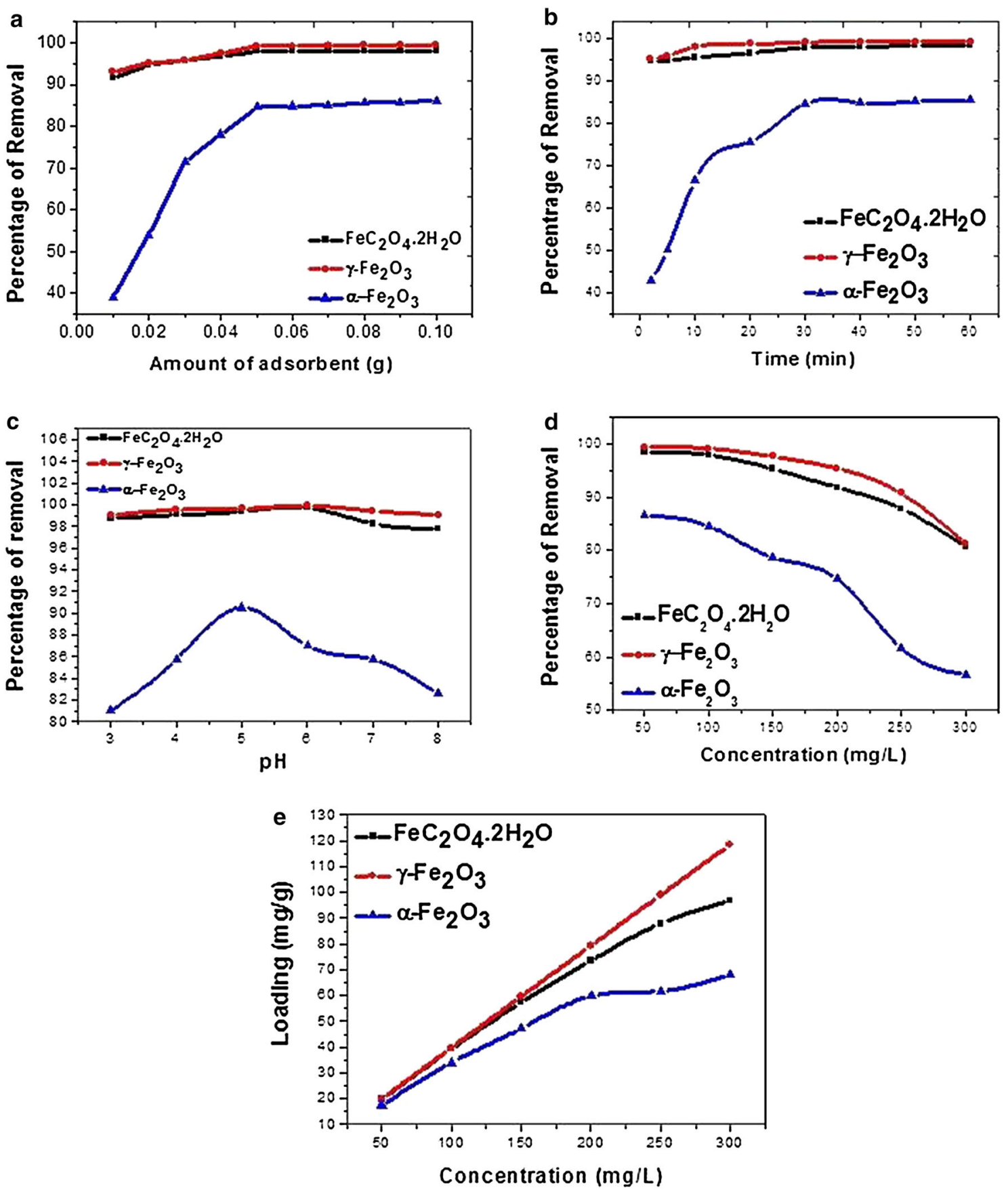

Fig. 8 Effect of a amount of adsorbent (dose), b time, $\mathbf{c} p H$ and $\mathbf{d}$ concentration on removal of CR by: square $\mathrm{FeC}_{2} \mathrm{O}_{4} \cdot 2 \mathrm{H}_{2} \mathrm{O}$, circle $\gamma-\mathrm{Fe}_{2} \mathrm{O}_{3}$ and triangle $\alpha-\mathrm{Fe}_{2} \mathrm{O}_{3}$ nanorods and $\mathbf{e}$ effect of initial dye concentration on adsorption capacity for the removal of CR

$\mathrm{CR}$ is found to be $97.97 \%$ for $\mathrm{FeC}_{2} \mathrm{O}_{4} \cdot 2 \mathrm{H}_{2} \mathrm{O}, 99.24 \%$ for $\gamma-$ $\mathrm{Fe}_{2} \mathrm{O}_{3}$ and $84.62 \%$ for $\alpha-\mathrm{Fe}_{2} \mathrm{O}_{3}$ for 30 min contact time. Agitation time of $30 \mathrm{~min}$ was selected for further works.

\section{Effect of pH on CR solution}

To investigate the effect of $\mathrm{pH}$ on the adsorption of $\mathrm{CR}$ dye, the $\mathrm{pH}$ range $3-8$ was chosen. The $\mathrm{pH}$ of the test solutions was adjusted by using $\mathrm{HCl}$ and $\mathrm{NaOH}$ solutions. An amount of $0.05 \mathrm{~g}$ of each adsorbents were used in $20 \mathrm{~mL}$ of $100 \mathrm{mg} \mathrm{L}^{-1} \mathrm{CR}$ solution of each $\mathrm{pH}$ with $30 \mathrm{~min}$ agitation time. From Fig. 8c, it is found that for $\mathrm{FeC}_{2} \mathrm{O}_{4} \cdot 2 \mathrm{H}_{2} \mathrm{O}$ and $\gamma-$ $\mathrm{Fe}_{2} \mathrm{O}_{3}$, there is no significant change in the percentage adsorption by increasing $\mathrm{pH}$ from 3 to 6 and reached maximum at $\mathrm{pH} 6$ and then slightly decreased at higher $\mathrm{pH}$ in case of $\mathrm{FeC}_{2} \mathrm{O}_{4} \cdot 2 \mathrm{H}_{2} \mathrm{O}$. For $\alpha-\mathrm{Fe}_{2} \mathrm{O}_{3}$, the maximum percentage of removal occurs at $\mathrm{pH} 5$ and then decreases. This is due to at higher $\mathrm{pH}$, the adsorbents surface become negatively 
charged. Therefore the adsorbents did not favour the adsorption of negatively charged CR dye due to electrostatic repulsion (Afkhami and Moosavi 2010).

\section{Effect of initial dye concentration on adsorption}

The adsorption is greatly influenced by the concentration of the solution, as the adsorptive reactions are directly proportional to the concentration of the solute (Mittal et al. 2009). It this section, $0.05 \mathrm{~g}$ of each adsorbent used each $20 \mathrm{~mL}$ of $\mathrm{CR}$ solution (natural $\mathrm{pH}$ ) with concentration ranging from 50 to $300 \mathrm{mg} \mathrm{L}^{-1}$ and the agitation time was kept $30 \mathrm{~min}$. It is found that with the increase in initial dye concentration, percentage adsorption decreases (Fig. 8d) while the equilibrium adsorption capacity of the adsorbent for CR increases with increasing initial dye concentration, i.e., the more concentrated the dye solution, the higher the adsorption capacity (Fig. 8e). This is probably due to a high driving force for mass transfer in high dye concentration.

\section{Adsorption isotherm}

To determine equilibrium relationship of amount adsorbed by a unit weight of adsorbent $\left(q_{\mathrm{e}}\right)$ with the concentration of adsorbent remaining in the medium at equilibrium $\left(C_{\mathrm{e}}\right)$, studies of various adsorption isotherm models are required. There is various type of adsorption models developed such as Freundlich, Langmuir, Tempkin and D-R isothermal models. (Mittal et al. 2009). The most common models such as Freundlich and Langmuir equations are used to investigation of this study.

\section{Langmuir isotherm}

The Langmuir isotherm model assumes monolayer coverage of adsorbate on a homogeneous adsorbent surface. This model does not consider surface heterogeneity of the sorbent. It assumes adsorption will take place only at specific site on the adsorbent (Chatterjee et al. 2009). The Langmuir equation is given as:

$\frac{q_{\mathrm{e}} a_{\mathrm{L}}}{K_{\mathrm{L}}}=\frac{K_{\mathrm{L}} C_{\mathrm{e}}}{\left(1+K_{\mathrm{L}} C_{\mathrm{e}}\right)}$

The linear form of the Langmuir isotherm is:

$$
\frac{C_{\mathrm{e}}}{q_{\mathrm{e}}}=\frac{1}{K_{\mathrm{L}} q_{\max }}+C_{\mathrm{e}} / q_{\max }
$$

where $a_{\mathrm{L}}\left(\mathrm{L} \mathrm{mg}^{-1}\right)$ and $K_{\mathrm{L}}\left(\mathrm{L} \mathrm{g}^{-1}\right)$ are the Langmuir constants, $\quad q_{\max }\left(=K_{\mathrm{L}} / a_{\mathrm{L}}\right)$ is the maximum adsorption capacity corresponding to complete monolayer coverage $\left(\mathrm{mg} \mathrm{g}^{-1}\right)$, which depends upon the number of adsorption sites (Rahimi et al. 2011). The values of $q_{\max }$ and $K_{\mathrm{L}}$ are calculated from the slopes and intercepts of the straight lines of plot of $C_{\mathrm{e}} / q_{\mathrm{e}}$ versus $C_{\mathrm{e}}$.

\section{Freundlich isotherm}

The Freundlich isotherm model is an empirical equation that describes the surface heterogeneity of the sorbent. It considers multilayer adsorption with a heterogeneous energetic distribution of active sites, accompanied by interactions between adsorbed molecules (Namasivayam and Kavitha 2002). The Freundlich isotherm equation is given as:

$q_{\mathrm{e}}=K_{\mathrm{F}} C_{\mathrm{e}}^{1 / n}$

The linear form of the Freundlich isotherm is:

$\ln q_{\mathrm{e}}=\ln K_{\mathrm{F}}+1 / n \ln C_{\mathrm{e}}$

where $C_{\mathrm{e}}$ is the equilibrium concentration $\left(\mathrm{mg} \mathrm{L}^{-1}\right), q_{\mathrm{e}}$ is the amount adsorbed at equilibrium $\left(\mathrm{mg} \mathrm{g}^{-1}\right)$ and $K_{\mathrm{F}}$ and $n$ are Freundlich constants, related to the extent of the adsorption and the degree of nonlinearity between solution concentration and adsorption, respectively. $K_{\mathrm{F}}$ and (1/ $n$ ) can be determined from the linear plot of $\ln q_{\mathrm{e}}$ versus $\ln C_{\mathrm{e}}$.

The essential characteristics of Langmuir isotherm can be expressed by a dimensionless constant called equilibrium parameter $\left(R_{\mathrm{L}}\right)$ that is defined by the following equation (Chatterjee et al. 2009; Afkhami et al. 2009):

$R_{\mathrm{L}}=\frac{1}{1+a_{\mathrm{L}} C_{0}}$

where $a_{\mathrm{L}}$ and $C_{0}$ are the parameters as defined previously. The value of $R_{\mathrm{L}}$ calculated from the above expression. The nature of the adsorption process to be either unfavorable $\left(R_{\mathrm{L}}>1\right)$, linear $\left(R_{\mathrm{L}}=1\right)$, favorable $\left(0<R_{\mathrm{L}}<1\right)$ or irreversible $\left(R_{\mathrm{L}}=0\right)$ (Lian et al. 2009). Here, $R_{\mathrm{L}}$ values obtained are listed in Table 2. The linear Langmuir and Freundlich plots for the adsorption of CR onto the three

Table 2 Adsorption isotherm constants for adsorption of CR

\begin{tabular}{llllll}
\hline Adsorbent & $\begin{array}{l}a_{\mathrm{L}} \\
\left(\mathrm{L} \mathrm{mg}^{-1}\right)\end{array}$ & $\begin{array}{l}K_{\mathrm{L}} \\
\left(\mathrm{L} \mathrm{g}^{-1}\right)\end{array}$ & $\begin{array}{l}q_{\mathrm{max}} \\
\left(\mathrm{mg} \mathrm{g}^{-1}\right)\end{array}$ & $r_{\mathrm{L}}^{2}$ & $R_{\mathrm{L}}$ \\
\hline Langmuir & & & & & \\
$\mathrm{FeC}_{2} \mathrm{O}_{4} \cdot 2 \mathrm{H}_{2} \mathrm{O}$ & 0.0022 & 0.224 & 103.09 & 0.996 & 0.82 \\
$\gamma-\mathrm{Fe}_{2} \mathrm{O}_{3}$ & 0.0012 & 0.267 & 232.56 & 0.998 & 0.89 \\
$\alpha-\mathrm{Fe}_{2} \mathrm{O}_{3}$ & 0.00064 & 0.048 & 78.13 & 0.995 & 0.999 \\
\hline Adsorbent & $K_{\mathrm{F}}$ & $1 / n$ & $r_{\mathrm{F}}^{2}$ & & \\
\hline Freundlich & & & & & \\
$\mathrm{FeC}_{2} \mathrm{O}_{4} \cdot 2 \mathrm{H}_{2} \mathrm{O}$ & 26.5 & 0.3493 & 0.957 & & \\
$\gamma-\mathrm{Fe}_{2} \mathrm{O}_{3}$ & 46.42 & 0.7434 & 0.993 & & \\
$\alpha-\mathrm{Fe}_{2} \mathrm{O}_{3}$ & 8.99 & 0.442 & 0.914 & & \\
\hline
\end{tabular}


Fig. 9 Linearization of Langmuir plots of a $\mathrm{FeC}_{2} \mathrm{O}_{4} \cdot 2 \mathrm{H}_{2} \mathrm{O}, \mathbf{b} \gamma-\mathrm{Fe}_{2} \mathrm{O}_{3}$ and c $\alpha-\mathrm{Fe}_{2} \mathrm{O}_{3}$ and Freundlich plots of $\mathbf{d} \mathrm{FeC}_{2} \mathrm{O}_{4} \cdot 2 \mathrm{H}_{2} \mathrm{O}$, e $\gamma-\mathrm{Fe}_{2} \mathrm{O}_{3}$ and $\mathbf{f} \alpha-\mathrm{Fe}_{2} \mathrm{O}_{3}$ for the adsorption of $\mathrm{CR}$
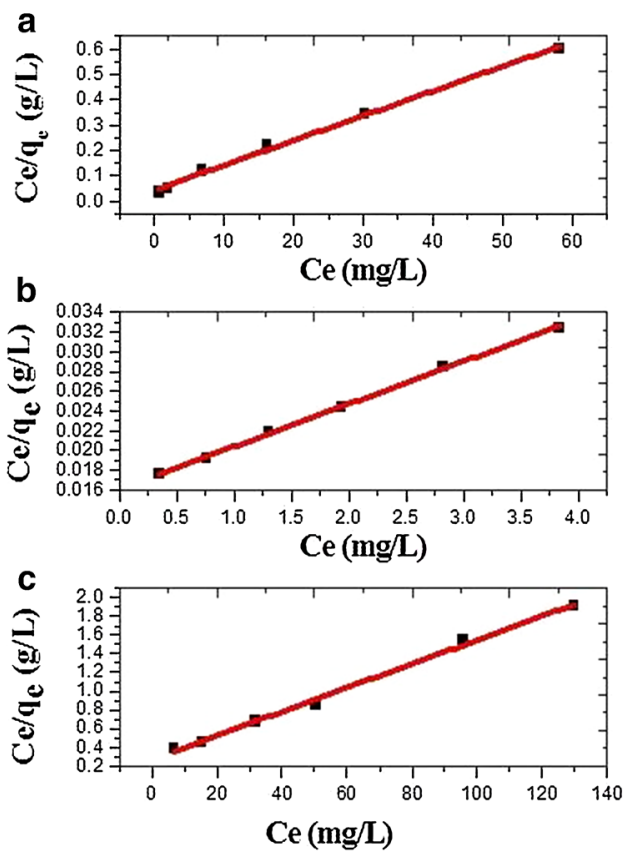
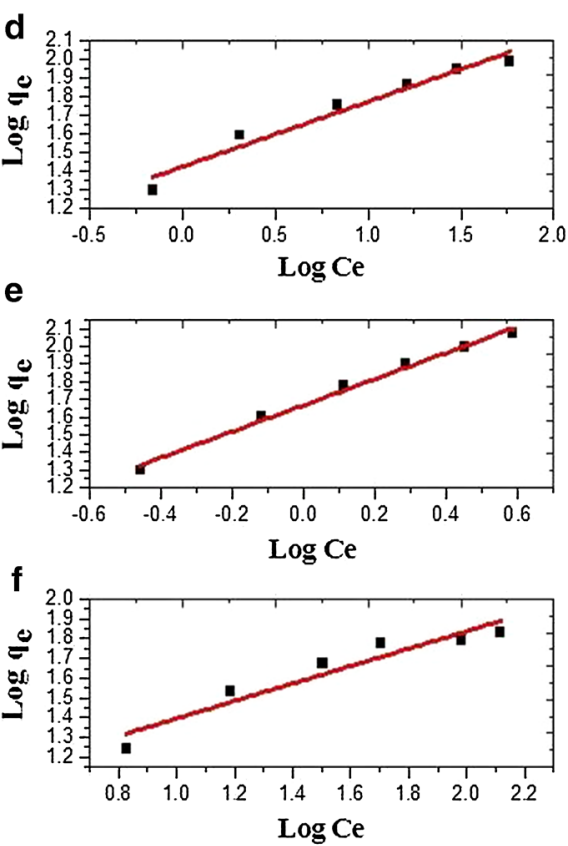

nanorod adsorbents are obtained by plotting $C_{\mathrm{e}} / q_{\mathrm{e}}$ versus $C_{\mathrm{e}}$ and $\ln q_{\mathrm{e}}$ versus $\ln C_{\mathrm{e}}$, respectively (given in Fig. 9). The isotherm constants and correlation coefficients were calculated and listed in Table 2. By comparing the correlation coefficients $r_{\mathrm{L}}^{2}$, it can be deduced that the experimental equilibrium adsorption data are well described by both the Langmuir and Freundlich models, but the Langmuir model is more suitable. The maximum adsorption capacity of $103.09,232.56$ and $78.13 \mathrm{mg} \mathrm{g}^{-1}$ was found for $\mathrm{FeC}_{2} \mathrm{O}_{4} \cdot 2 \mathrm{H}_{2} \mathrm{O}, \gamma-\mathrm{Fe}_{2} \mathrm{O}_{3}$ and $\alpha-\mathrm{Fe}_{2} \mathrm{O}_{3}$, respectively. For Freundlich isotherm model, the $\mathrm{n}$ value between 1 and 10 indicates beneficial adsorption (Chen and Zhao 2009). Comparing the $q_{\max }$ values of the different adsorbents, it is observed that $\gamma-\mathrm{Fe}_{2} \mathrm{O}_{3}$ nanorod has higher adsorption capacity than $\mathrm{FeC}_{2} \mathrm{O}_{4} \cdot 2 \mathrm{H}_{2} \mathrm{O}$ and $\alpha-\mathrm{Fe}_{2} \mathrm{O}_{3}$ nanorods.

\section{Adsorption kinetics}

In order to investigate the adsorption processes of CR on the adsorbents, pseudo-second-order kinetic is used. The pseudo-second-order model is represented as (Ho and McKay 1999):

$\frac{t}{q}=\frac{1}{k_{2} q_{\mathrm{e}}^{2}}+\frac{t}{q_{\mathrm{e}}}$

And the initial adsorption rate, $h\left(\mathrm{mg} \mathrm{g}^{-1} \min ^{-1}\right)$, as $t \rightarrow 0$ can be defined as:

$h=k_{2} q_{\mathrm{e}}^{2}$
The initial adsorption rate $(h)$, the equilibrium adsorption capacity $\left(q_{\mathrm{e}}\right)$ and the second-order constants $k_{2}$ ( $\mathrm{g}^{-1} \mathrm{mg} \min$ ) can be determined experimentally from the slope and intercept of plot of $t / q$ versus $t$. The best-fit values of $h, q_{\mathrm{e}}$ and $k_{2}$ along with correlation coefficients of the pseudo-second-order model for the three adsorbents are shown in Table 3, and the pseudo-second-order plots of $\mathrm{FeC}_{2} \mathrm{O}_{4} \cdot 2 \mathrm{H}_{2} \mathrm{O}, \gamma-\mathrm{Fe}_{2} \mathrm{O}_{3}$ and $\alpha-\mathrm{Fe}_{2} \mathrm{O}_{3}$ are given in Fig. 10. The values of predicted equilibrium adsorption capacities $\left(q_{\mathrm{e}}\right)$ showed good agreement with the experimental equilibrium uptake values. Similarly, correlation coefficients are always greater than 0.99 , which also explains the good fit of the model.

The maximum adsorption capacity $\left(q_{\max }\right)$ for the adsorption of CR on $\gamma-\mathrm{Fe}_{2} \mathrm{O}_{3}$ nanorod compared to other adsorbents is listed in Table 4. It is observed that the prepared $\gamma-\mathrm{Fe}_{2} \mathrm{O}_{3}$ nanorod is an efficient adsorbent for adsorption of $\mathrm{CR}$ from aqueous solution.

Table 3 Second-order kinetic parameters for the removal of CR

\begin{tabular}{lllll}
\hline Adsorbents & $\begin{array}{l}K_{2}\left(\mathrm{~g} \mathrm{mg}^{-1}\right. \\
\left.\mathrm{min}^{-1}\right)\end{array}$ & $\begin{array}{l}q_{\mathrm{e}} \\
\left(\mathrm{mg} \mathrm{g}^{-1}\right)\end{array}$ & $\begin{array}{l}q_{\mathrm{e}}\left(\mathrm{mg} \mathrm{g}^{-1}\right) \\
(\text { experimental })\end{array}$ & $r^{2}$ \\
\hline $\mathrm{FeC}_{2} \mathrm{O}_{4} \cdot 2 \mathrm{H}_{2} \mathrm{O}$ & 0.0999 & 39.53 & 39.19 & 1 \\
$\gamma-\mathrm{Fe}_{2} \mathrm{O}_{3}$ & 0.0933 & 40 & 39.7 & 1 \\
$\alpha-\mathrm{Fe}_{2} \mathrm{O}_{3}$ & 0.00891 & 36.23 & 34.23 & 0.9986 \\
\hline
\end{tabular}


a

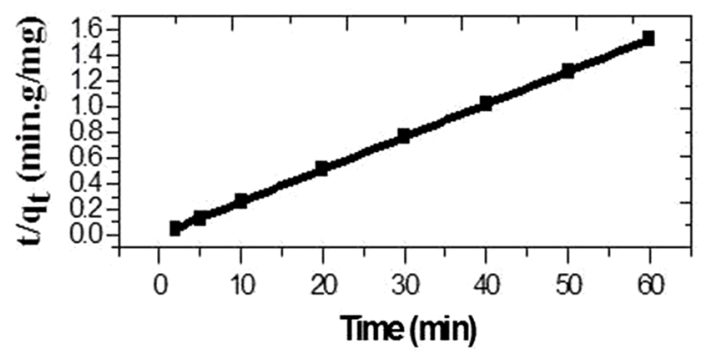

b

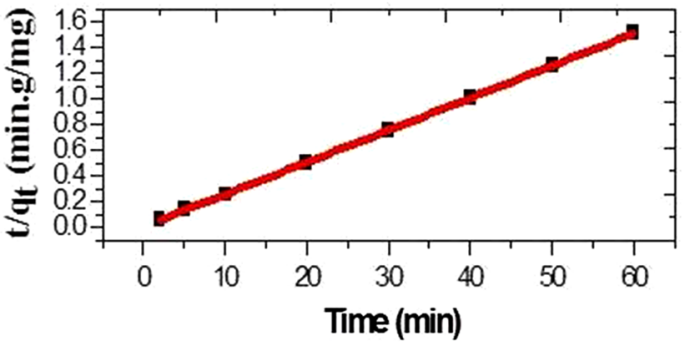

c

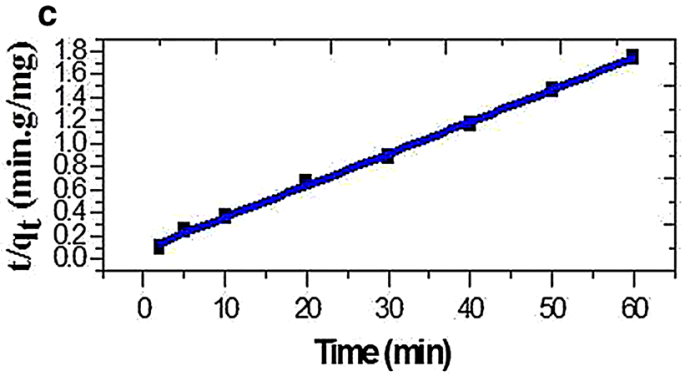

Fig. 10 Pseudo-second-order kinetic plots of a $\mathrm{FeC}_{2} \mathrm{O}_{4} \cdot 2 \mathrm{H}_{2} \mathrm{O}$, b $\gamma$ $\mathrm{Fe}_{2} \mathrm{O}_{3}$ and $\mathbf{c} \alpha-\mathrm{Fe}_{2} \mathrm{O}_{3}$

Table 4 Comparison of CR adsorption capacities of various adsorbents

\begin{tabular}{lcl}
\hline Types of adsorbent & $\begin{array}{l}q_{\max } \\
\left(\mathrm{mg} \mathrm{g}^{-1}\right)\end{array}$ & References \\
\hline $\begin{array}{l}\text { Chitosan/montmorillonite } \\
\text { nanocomposite }\end{array}$ & 54.52 & Wang and Wang (2007) \\
$\begin{array}{l}\text { Montmorillonite } \\
\text { Mesoporous activated }\end{array}$ & 12.70 & Wang and Wang (2007) \\
carbons & 189 & $\begin{array}{c}\text { Lorenc-Grabowska and } \\
\text { Gryglewicz (2007) }\end{array}$ \\
$\gamma-\mathrm{Fe}_{2} \mathrm{O}_{3}$ nanoparticles & 208.33 & Afkhami and Moosavi (2010) \\
$\mathrm{Chitosan}$ Bead & 162.32 & Chatterjee et al. (2009) \\
$\gamma-\mathrm{Fe}_{2} \mathrm{O}_{3}$ nanorod & 232.56 & Present work \\
$\mathrm{FeC}_{2} \mathrm{O}_{4} \cdot 2 \mathrm{H}_{2} \mathrm{O}$ nanorod & 103.09 & Present work \\
$\alpha-\mathrm{Fe}_{2} \mathrm{O}_{3}$ nanorod & 78.13 & Present work \\
\hline
\end{tabular}

\section{Conclusion}

In this present study, we have synthesized ferrous oxalate nanorods by a modified co-precipitation by using ferrous sulfate and oxalic acid as starting material and CTAB as surfactant. Then the obtained nanoparticles are calcined at higher temperature to form $\gamma-\mathrm{Fe}_{2} \mathrm{O}_{3}$ and $\alpha-\mathrm{Fe}_{2} \mathrm{O}_{3}$ nanorods. SEM images indicate the formation of rod-shaped nanoparticles with diameter around 100-200 $\mathrm{nm}$ and length up to micrometers. The formation of the phase, crystallite sites, lattice parameters, lattice strains and crystal structure are determined by XRD study. It is found that the crystallite sizes are 22.6, 29.4 and $39.1 \mathrm{~nm}$, for $\mathrm{FeC}_{2} \mathrm{O}_{4} \cdot 2 \mathrm{H}_{2} \mathrm{O}, \gamma-\mathrm{Fe}_{2} \mathrm{O}_{3}$ and $\alpha-\mathrm{Fe}_{2} \mathrm{O}_{3}$ nanorods, respectively. Further confirmation of formation is done by FTIR using the different vibrational peaks. The electronic transition of $\mathrm{Fe}^{+2}$ ion for $\mathrm{FeC}_{2} \mathrm{O}_{4}$. $2 \mathrm{H}_{2} \mathrm{O}$ and $\mathrm{Fe}^{+3}$ for $\gamma-\mathrm{Fe}_{2} \mathrm{O} 3$ and $\alpha-\mathrm{Fe}_{2} \mathrm{O}_{3}$ was studied by UV-vis DRS spectra. From this spectra, energy band gap was calculated and found to be 2.24, 1.95 and $2.04 \mathrm{eV}$ for $\mathrm{FeC}_{2} \mathrm{O}_{4} \cdot 2 \mathrm{H}_{2} \mathrm{O}, \gamma-\mathrm{Fe}_{2} \mathrm{O}_{3}$ and $\alpha-\mathrm{Fe}_{2} \mathrm{O}_{3}$, respectively, which confirms that all the three nanorods possess semiconducting properties with narrow band gap. Then, the three prepared 1-dimensional nanomaterials such as ferrous oxalate nanorod, maghemite $\left(\gamma-\mathrm{Fe}_{2} \mathrm{O}_{3}\right)$ nanorod and hematite $\left(\alpha-\mathrm{Fe}_{2} \mathrm{O}_{3}\right)$ nanorod were used as adsorbent for removal of carcinogenic organic dye such as CR from aqueous solution. From the adsorption study, it is found that the maximum adsorption capacities of the adsorbents are 103.09, 232.56 and $78.13 \mathrm{mg} \mathrm{g}^{-1}$ for $\mathrm{FeC}_{2} \mathrm{O}_{4} \cdot 2 \mathrm{H}_{2} \mathrm{O}, \gamma-\mathrm{Fe}_{2} \mathrm{O}_{3}$ and $\alpha-\mathrm{Fe}_{2} \mathrm{O}_{3}$ nanorods, respectively. This result indicates that among the three prepared 1-dimensional nanomaterials, $\gamma-\mathrm{Fe}_{2} \mathrm{O}_{3}$ nanorods are the most effective adsorbent for the adsorption of CR from aqueous solution.

Acknowledgments The authors would like to acknowledge National Institute of Technology Rourkela, Odisha, India for providing the research funding and facilities to carry out this research work.

\section{References}

Afkhami A, Moosavi R (2010) Adsorptive removal of Congo red, a carcinogenic textile dye, from aqueous solutions by maghemite nanoparticles. J Hazard Mater 174:398-403

Afkhami A, Saber-Tehran M, Bagheri H (2009) Modified maghemite nanoparticles as an efficient adsorbent for removing some cationic dyes from aqueous solution. Desalination 263:240-248

Bhattacharyya KG, Sharma A (2004) Azadirachta indica leaf powder as an effective biosorbent for dyes: a case study with aqueous Congo red solutions. J Environ Manage 71:217-229

Binupriya AR, Sathishkumar M, Swaminathan K, Ku CS, Yun SE (2008) Comparative studies on removal of Congo red by native and modified mycelial pellets of Trametes versicolor in various reactor modes. Bioresour Technol 99:1080-1088

Chakraborty S, Purkait MK, Dasgupta S, De S, Basu JK (2003) Nanofiltration of textile plant effluent for color removal and reduction in COD. Sep Purif Technol 31:141-151

Chan LS, Cheung WH, Allen SJ, McKay G (2009) Separation of aciddyes mixture by bamboo derived active carbon. Sep Purif Technol 67:166-172

Chatterjee S, Lee MW, Woo SH (2009) Enhanced adsorption of congo red from aqueous solutions by chitosan hydrogel beads impregnated with cetyl trimethyl ammonium bromide. Bioresour Technol 100:2803-2809 
Chatterjee S, Lee MW, Woo SH (2010) Adsorption of congo red by chitosan hydrogel beads impregnated with carbon nanotubes. Bioresour Technol 101:1800-1806

Chen H, Zhao J (2009) Adsorption study for removal of Congo red anionic dye using organo-attapulgite. Adsorption 15:381-389

Chowdhury AK, Sarkar AD, Bandyopadhyay A (2009) Rice Husk Ash as a Low Cost Adsorbent for the Removal of Methylene Blue and Congo red in Aqueous Phases. Clean -Soil Air. Water 37(7):581-591

Dawood S, Sen TK (2012) Removal of anionic dye Congo red from aqueous solution by raw pine and acid-treated pine cone powder as adsorbent: equilibrium, thermodynamic, kinetics, mechanism and process design. Water Res 46:1933-1946

Dizge N, Aydiner C, Demirbas E, Kobya M, Kara S (2008) Adsorption of reactive dyes from aqueous solutions by fly ash: kinetic and equilibrium studies. J Hazard Mater 150:737-746

Fu Y, Viraraghavan T (2002) Removal of Congo red from an aqueous solution by fungus Aspergillus niger. Adv Environ Res 7:239-247

Ge F, Ye H, Li MM, Zhao BX (2012) Efficient removal of cationic dyes from aqueous solution by polymer-modified magnetic nanoparticles. Chem Eng J 198-199:11-17

Haider S, Bukhari N, Park SY, Iqbal Y, Al-Masry WA (2011) Adsorption of bromo-phenol blue from an aqueous solution onto thermally modified granular charcoal. Chem Eng Res Des 89:23-28

Ho YS, McKay G (1999) Pseudo-second order model for sorption processes. Process Biochem 34:451-465

Hu J, Song Z, Chen L, Yang H, Li J, Richards R (2010a) Adsorption Properties of $\mathrm{MgO}(111)$ Nanoplates for the Dye Pollutants from Wastewater. J Chem Eng Data 55:3742-3748

Hu Z, Chen H, Ji F, Yuan S (2010b) Removal of Congo red from aqueous solution by cattail root. J Hazard Mater 173:292-297

Irama M, Guo C, Guan Y, Ishfaq A, Liu H (2010) Adsorption and magnetic removal of neutral red dye from aqueous solution using Fe3O4 hollow nanospheres. J Hazard Mater 181:1039-1050

Jain R, Sikarwar S (2008) Removal of hazardous dye congo red from waste material. J Hazard Mater 152:942-948

Khadhraoui M, Trabelsi H, Ksibi M, Bouguerra S, Elleuch B (2009) Discoloration and detoxification of Congo red dye solution by means of ozone treatment for a possible water reuse. J Hazard Mater 161:974-981

Kumar J, Bansal A (2012) Photodegradation of amaranth in aqueous solution catalyzed by immobilized nanoparticles of titanium dioxide. Int J Environ Sci Technol 9(3):479-484. doi:10.1007/ s13762-012-0064-4

Lian L, Guo L, Guo C (2009) Adsorption of Congo red from aqueous solutions onto Ca-bentonite. J Hazard Mater 161:126-131

Lorenc-Grabowska E, Gryglewicz G (2007) Adsorption characteristics of Congo red on coal-based mesoporous activated carbon. Dyes Pigm 74:34-40

Lucas MS, Peres JA (2006) Decolorization of the azo dye Reactive Black 5 by Fenton and photo-Fenton oxidation. Dyes Pigments 71:236-244

Marechal ML, Slokar YM, Taufer T (1997) Decolouration of chlorotriazine reactive azo dyes with $\mathrm{H}_{2} \mathrm{O}_{2} / \mathrm{UV}$. Dyes Pigments 33:281-298

Miller EL, Paluselli D, Marsen B, Rocheleau RE (2004) Lowtemperature reactively sputtered iron oxide for thin film devices. Thin Solid Films 466:307-313

Mittal A, Mittal J, Malviya A, Gupta VK (2009) Adsorptive removal of hazardous anionic dye "Congo red" from wastewater using waste materials and recovery by desorption. J Colloid Interface Sci 340:16-26

Namasivayam C, Kavitha D (2002) Removal of Congo red from water by adsorption onto activated carbon prepared from coir pith, an agricultural solid waste. Dyes Pigm 54:47-58

Nethaji S, Sivasamy A, Mandal AB (2012) Adsorption isotherms, Kinetics and mechanisms for the adsorption of cationic and anionic dyes onto carbonaceous particles prepared from Juglans regia shell biomass. Int J Environ Sci Technol 10(2):231-242

Panda GC, Das SK, Guha AK (2009) Jute stick powder as a potential biomass for the removal of congo red and rhodamine B from their aqueous solution. J Hazard Mater 164:374-379

Pavan FA, Dias SLP, Lima EC, Benvenutti EV (2008) Removal of Congo red from aqueous solution by anilinepropylsilica xerogel. Dyes Pigm 76:64-69

Purkait MK, Dasgupta S, De S (2004) Removal of dye from wastewater using micellar-enhanced ultrafiltration and recovery of surfactant. Sep Purif Technol 37:81-92

Purkait MK, Maiti A, Dasgupta S, De S (2007) Removal of congo red using activated carbon and its regeneration. J Hazard Mater 145:287-295

Rahimi R, Kerdari H, Rabbani M, Shafiee M (2011) Synthesis, characterization and adsorbing properties of hollow $\mathrm{Zn}-\mathrm{Fe}_{2} \mathrm{O}_{4}$ nanospheres on removal of congo red from aqueous solution. Desalination 280:412-418

Sachdeva S, Kumar A (2009) Preparation of nonporous composite carbon membrane for separation of Rhodamine B dye. J Membr Sci 329:2-10

Sherman DM, Waite TD (1985) Electronic spectra of $\mathrm{Fe}^{3+}$ oxides and oxide hydroxides in the near IR to near UV. Am Mineral 70:1262-1269

Song YL, Li JT, Chen H (2009) Degradation of C.I. Acid red 88 aqueous solution by combination of Fenton's reagent and ultrasound irradiation. J Chem Technol Biotechnol 84:578-583

Song HJ, Liu L, Jia XH, Min C (2012) Synthesis of multi-walled carbon nanotubes/ $\beta$-FeOOH nanocomposites with high adsorption capacity. J Nanopart Res 14:1-8

Toor M, Jin B (2012) Adsorption characteristics, isotherm, kinetics, and diffusion of modified natural bentonite for removing diazo dye. Chem Eng J 187:79-88

Vijayakumar G, Dharmendirakumar M, Renganathan S, Sivanesan S, Baskar G, Elango KP (2009) Removal of Congo red fromAqueous Solutions by Perlite. Clean-Soil Air Water 37(4-5):355-364

Wang L, Wang A (2007) Adsorption characteristics of congo red onto the chitosan/montmorillonite nanocomposite. J Hazard Mater 147:979-985

Wang L, Wang A (2008) Adsorption properties of Congo red from aqueous solution onto surfactant-modified montmorillonite. J Hazard Mater 160:173-180

Wang L, Li J, Wang Y, Zhao L, Jiang Q (2012a) Adsorption capability for Congo red on nanocrystalline $\mathrm{MFe}_{2} \mathrm{O}_{4}(\mathrm{M}=\mathrm{Mn}$, $\mathrm{Fe} \mathrm{Co}, \mathrm{Ni}$ ) spinel ferrites. Chem Eng J 181-182:72-79

Wang L, Wu XL, Xu WH, Huang XJ, Liu JH, Xu AW (2012b) Stable Organic-Inorganic Hybrid of Polyaniline/ $\alpha$-Zirconium Phosphate for Efficient Removal of Organic Pollutants in Water Environment. ACS Appl. Mater. Interfaces 4:2686-2692

Wawrzkiewicz M (2012) Comparison of the efficiency of amberlite IRA 478RF for acid, reactive, and direct dyes removal from aqueous media and wastewaters. Ind Eng Chem Res 51:8069-8078

Wawrzkiewicz M, Hubicki Z (2010) Equilibrium and kinetic studies on the sorption of acidic dye bymacro porous anion exchange. Chem Eng J 157:29-34

Yosef I, Avnir D (2011) Entrapment of dye molecules within submicron silver particles. J Nanopart Res 13:3929-3937

Yu C, Dong X, Guo L, Li J, Qin F, Zhang L, Shi J, Yan D (2008) Template-free preparation of mesoporous $\mathrm{Fe}_{2} \mathrm{O}_{3}$ and its application as absorbents. J Phys Chem C 112:13378-13382

Zhu M, Wang Y, Meng D, Qin X, Diao G (2012a) Hydrothermal synthesis of hematite nanoparticles and their electrochemical properties. J Phys Chem C 116:16276-16285

Zhu T, Chen JS, Lou XWD (2012b) Highly efficient removal of organic dyes from waste water using hierarchical $\mathrm{NiO}$ spheres with high surface area. J Phys Chem C116:6873-6878 